\title{
Paremäärmuslik sõnavabadus eesti rahvusradikaalide veebisuhtluses ${ }^{1}$
}

\author{
Mari-Liis Madisson, Andreas Ventsel
}

Teesid: Artikli fookuses on eesti paremäärmuslaste enesekirjelduste eripärad hüpermeedias. Tänapäevased paremäärmuslikud liikumised kombineerivad oma etnotsentristlike vaadete avalikuks legitimeerimiseks rahvusradikaalseid ideid üldaktsepteeritud (eelkõige liberaaldemokraatliku maailmavaatega seonduvate) tähistajatega, nt vabadus, võrdsus, demokraatia, sõnavabadus jne. Niisuguse pealtnäha kokkusobimatuid diskursusi koondava tähendusloome selgitamiseks toetume Roger Griffini grupuskuli kontseptsioonile, Ernesto Laclau diskursuseteoreetilisele lähenemisele ja kultuurisemiootikale. Meie juhtumiuuring põhineb ACTA ratifitseerimise protsessi reflektsioonil eesti paremäärmuslaste blogides. Võltsimisvastane kaubandusleping muutus 2012. aasta alguses eesti paremäärmuslaste enesekirjeldustes üheks oluliseks tuumtähistajaks.

Märksõnad: ACTA ratifitseerimine, enesemudel, Essexi koolkonna diskursuseteooria, identiteediloome hüpermeedias, kultuurisemiootika, paremäärmuslus

Käesolev uurimus keskendub paremäärmuslikes veebikogukondades prevaleerivatele identiteediloome suundumustele. Tänapäevase paremäärmusliku kommunikatsiooni uurimisel tuleb silmas pidada, et tegemist on keeruka ja mitmekihilise uurimisobjektiga, mis ei eksisteeri valitsevatest diskursiivsetest trendidest ja hüpermeedia uudsetest tähistamisiseärasustest eraldi. Rahvuslust ja rassismiküsimusi uuriv sotsioloog Les Back on osutanud, et paremäärmuslust on sageli otstarbekas mõtestada kui voolavaid ideoloogiaid (ingl liquid ideologies). Voolavate ideoloogiate all peab ta silmas pealtnäha paradoksaalset suundumust, kus paremäärmuslased on hakanud integreerima dominantse, normaliseeritud diskursuse elemente (nt multikulturalismi diskursuse tuumtähistajaid) oma rassistlikesse meediapraktikatesse, luues kummastavaid transformatsioone (Back 2002a). Sarnasele, iseäranis online-suhtluses esile kerkinud suundumusele on viidanud ka paljud teised autorid (Atton 2006; Cammaerts 2009; Campbell 2006; Sommer 2008; Taguieff 1999 jt).

Tänapäevane paremäärmuslus allub suures osas vernakulaarse veebi loogikale, kus toimub info pidev ümbermodelleerimine ja transformeerimine eri- 
nevates kontekstides. Mitmed uurijad (Laas 2011; Landow 2006: 232; Soukup 2008: 14) on jõudnud järeldusele, et hüpermeedia vahendid lausa soodustavad autorite muutumist brikolöörideks, kes ehitavad oma tekstid juba olemasolevale materjalile, kusjuures loodud uudne tervik säilitab alati ka teatavad seosed oma osiste varasemate korrastustega. Niisugune brikollaaž võimaldab liikumist väga erinevate tekstisfääride vahel: uudsed tähistamisvõimalused lubavad ühendada fundamentaalselt erinevat informatsiooni ning ületada seega kõikvõimalikke klassikalisi žanripiire (Landow 2006: 60). Hübriidsesse tervikusse põimitakse sageli elemente nii n-ö ametlikust (nt riigiasutuste või ettevõtete koduleheküljed, ajaleheartiklid jne) kui ka amatöörlikust (nt ajaveebid, foorumipostitused ja sissekanded erinevatesse sotsiaalmeedia platvormidesse jne) infosfäärist, nii kunsti kui tarbetekstidest, nii individuaalsest kui kollektiivsest loomingust. Robert Glenn Howard on nimetanud niisugust hübriidset tekstiloomet tabavalt vernakulaarseks veebiks. Ta osutab, et tänapäevases online-kommunikatsioonis võib täheldada märkimisväärset folkloori võidukäiku, kuna nii visuaalsete kui ka verbaalsete tekstide omistamine konkreetsetele autoritele muutub üha problemaatilisemaks (Howard 2008: 203-204).

Siinse artikli peamine eesmärk on selgitada paremäärmuslaste vastandlikest väärtushinnangutest lähtuvaid identiteediloomeprotsesse, mis on kohandunud hüpermeedia tähistamise hübriidsete tingimustega. Seega ei ole meie eesmärk võrrelda paremäärmuslikku online-identifikatsiooni ning teiste peavoolu- või alternatiivmeedias levivaid enesekirjeldamise tavasid. Niisugune eesmärgipüstitus võiks leida rakendamist meie järgmistes uurimustes. Siinse artikli teoreetiline plaan sünteesib Tartu-Moskva koolkonna kultuurisemiootikast pärit enesekirjelduse ja enesemudeli kontseptsioone Essexi koolkonna hegemooniateooria ideedega. Meie uurimus toetub mitteosalevale vaatlusele, mida oleme teostanud eestikeelses paremäärmuslikus online-sfääris alates 2012. aasta algusest. Siinses artiklis keskendusime viie paremäärmusliku veebilehe diskursuse analüüsile. Les Backi järgi ühendab hüpermeedia vahendusel leviv diskursus suurt hulka subkultuurilisi liikumisi üleilmse arvutivõrgu kõige erinevamatest osadest. Need liikumised on väga varieeruva profiiliga, kuid neile on iseloomulikud järgmised ühisjooned: 1) rassilise ja/või rahvusliku unikaalsuse retoorika; 2) rassilise ja/või rahvusliku ülimuslikkuse, üleoleku, erakordsuse idee; 3) suur repertuaar rassilise teise kontseptualiseerimiseks, 4) utoopilis-revolutsiooniline maailmavaade, mis seab eesmärgiks eksisteeriva korra kukutamise (Back 2002b: 632). Valisime eetilistel kaalutlustel analüüsimiseks veebileheküljed, mis vahendavad (eelpool toodud nelja tunnuse kaudu määratletavat) paremäärmuslikku sõnumit ning millele on avalik juurdepääs. Seetõttu jäid välja leheküljed, millele ligipääsemist on piiratud paroolide ja kasutajanimedega. Külastajate arvu, teemapüstituste kontsentreerituse ja tsi- 
teeritavuse tõttu käsitlesime antud uurimuses eesti paremäärmusliku grupuskulaarse välja representatiivsete keskmetena järgmisi blogisid: Eesti Rahvuslik Blogi (rahvuslik.blogspot.com/), Rahvuslane (http://rahvuslane.blogspot.com/), Vabamõtleja (http://www.vabamotleja.info) ${ }^{2}$ ja NS Blog (http://nsblogi.com/) $)^{3}$ ning veebilehekülge BH Ruzzland (http://bhr.balanss.ee/), kuna siinkirjutajate arvates annavad need illustratiivse pildi eestikeelse grupuskulaarse välja tsentrist. Meie juhtumiuuring tugineb avalikkuses erakordset vastukaja leidnud ACTA (inglise keeles Anti-Counterfeiting Trade Agreement) ratifitseerimise protsessi reflektsioonidele. Nimetatud lepingu sihiks on sõnastada rahvusvahelised normid, mis lubaksid reguleerida intellektuaalomandiga seonduvaid õigusi. Leping püüab kehtestada rahvusvahelisi standardeid autoriõiguse rikkujate karistamiseks, et võidelda võltsimise, piraatluse ja teiste intellektuaalse omandi vastu suunatud kuritegudega. ACTA ratifitseerimisprotsessi arutelu Riigikogus viis 2012. aasta talvel mitmete protestiaktsioonide ja meeleavaldusteni, mis päädisid Rahvakogu kokkukutsumisega. Sõna- ja infovabaduse teema kujunes pikaks ajaks eesti meedia üheks peateemaks: see mängis olulist rolli nii parlamendivaidlustes, avalikes sõnavõttudes kui ka paremäärmuslaste enesekirjeldustes.

Käesoleva uurimuse valimi piiritlemisel keskendusime peamiselt blogipostitustele (kokku 31), kus otseselt kõneldi ACTAst või selle sotsiaalsetest mõjudest. Need postitused ilmusid valdavalt 2012. aasta esimesel poolel, aga olid ka mõned erandid. Kõige ulatuslikumalt leidis ACTA temaatika käsitlemist blogis Rahvuslane (22 postitust), kus tsiteeriti ka mitmeid teistes blogides, foorumites ja päevalehtedes ilmunud artikleid. NS Blogist analüüsisime 4 ja Vabamõtlejast samuti 4 postitust, Rahvuslikust blogist aga 1 postitust. Analüüsitud paremäärmuslikud leheküljed erinevad oma profillis suuresti: nii veebilehe ülesehituse poolest kui ka paremäärmusliku sõnumi intensiivsuse poolest. Näiteks on BH Ruzzland keskendunud valdaval russofoobiale, samas Rahvuslane pühendub pigem rahvusriikide allakäiguga seotud teemadele ning Rahvuslik käsitleb valge rassi (eelkõige valge mehe) tagakiusamist. Siinkohal peab osutama analüüsitava valimi koostamisega seotud raskustele, sest paremäärmuslikest liikumistest ei ole lihtne rääkida. Äärmuslus kannab meie kultuuriruumis kahtlemata negatiivseid konnotatsioone ning millegi määratlemine ekstremismina kätkeb endas alati teatavat stigmatiseerimise ohtu. Teisalt eeldab millegi äärmuslikuks pidamine alati selle suhestamist n-ö tunnetusliku normiga, mistõttu sõltuvad väärtuslikuks peetavad nähtused otseselt sellest, millega neid kõrvutatakse. Eesti kontrakultuurilisele avalikkusele on meie analüüsitud blogid suhteliselt tuntud, mõningad seal avaldatud artiklid või nende fragmendid ringlevad aktiivselt kohalikus blogosfääris, sotsiaalmeedias jne. Kusjuures ka meie uuritud blogides esineb üksteise postituste ristviitamist, 
aga ka otsest peavoolumeedias ilmunud uudis-ja arvamuslugude tsiteerimist. Paljuski just osutatud aspekti tõttu pole kõik blogides representeeritud tekstid eksplitsiitselt paremäärmuslikud ${ }^{4}$, st neid ei pruugi otseselt iseloomustada nativism, ksenofoobia, rassism, anti-liberaaldemokraatlikkus ja tugeva riigivõimu idealiseerimine, mida peetakse tänapäevase paremäärmusluse n-ö klassikalisteks tunnusteks (vt Mudde 1996: 229; Mudde 2011b: 7). Samas on kõigi analüüsitud allikate üldine tonaalsus paremäärmuslik, levinud ideedeks on näiteks põliseestluse hoidmise ja võõrmõjude eest kaitsmise vajadus; olemasoleva maailmakorra (sh Eesti võimustruktuuride) allumine sionistlikule/ massoonlikule salarühmitusele; rasside ja kultuuride segunemise ohtlikkus; seksuaalvähemuste ja feminismi taunimisväärsus. Teisalt osutab paremäärmusluse defineerimise raskustele ka käesoleva artikli probleemipüstitus - grupuskulite ideoloogiline enesekirjeldus lähtubki sageli vastuolulistest ideedest.

Artikli esimeses osas kirjeldame laiemalt paremäärmuslike liikumiste enesekirjeldusi, andmaks ülevaadet seal levivatest ideoloogilistest seisukohtadest. Teises osas püüame konkreetset juhtumit analüüsides näidata, kuidas $E I A C$ TAle kui tühi tähistaja hakkab kehastama diskursust, mis koondab endas kaht vastandlikku enesemudelit. Sellist, pealtnäha kokkusobimatuid enesemudeleid ühendavat kooslust võib tinglikult käsitleda paremäärmusliku sõnavabadusena. Ernesto Laclau diskursuseteoreetiline raamistik lubab selgitada, kuidas ehitub üles eripärane tähistamisprotsess, kus ühes tekstis eksisteerivad samaaegselt üksteisele vastanduvad rassistlikke ja demokraatlikke ideaale rõhutavad diskursused. Kultuurisemiootika enesekirjelduse ja enesemudeli kontseptsioonid püüavad aga heita valgust selle protsessi kontekstile ja diskursusesiseste elementide hierarhiale.

\section{Grupuskulaarne paremäärmuslus hüpermeedias}

Nagu valdav osa inimestevahelisest infovahetusest, on ka paremäärmuslik kommunikatsioon viimase paarikümne aasta jooksul üha enam kohandunud hüpermeedia võimalustega. Hüpermeedia vahendid on teinud võimalikuks uut tüüpi paremäärmusliku käitumise vormid (Back 2002b: 634). Kõige põhjalikumalt on tänapäevast paremäärmuslust, mille peamiseks levikukeskkonnaks on internet, selgitanud Roger Griffini grupuskulikäsitlus. On oluline märkida, et grupuskulaarne kommunikatsioon ei iseloomusta üksnes äärmusparempoolset suhtlemist, vaid on teatavate erinevustega omane kogu ekstremistlike kogukondade veebikommunikatsioonile. Griffini (2011: 53) järgi võib grupuskuleid määratleda kui tänapäevase äärmus-parempoolse poliitika kontekstis esile kerkinud väikseid poliitilisi (sageli metapoliitilisi, kuid peaaegu mitte kunagi 
otseselt parteipoliitilisi) üksusi, mis on moodustatud taotlemaks revolutsioonilisi, ideoloogilisi, organisatsioonilisi ja aktivistlikke eesmärke, ning "mille lõppsihiks on ületada olemasoleva liberaaldemokraatliku süsteemi dekadents". Paremäärmuslasi võlub tunne, et ilma toast lahkumata on nad aktiivse üleilmse virtuaalkogukonna liikmed (Griffin 2002: 6). Grupuskuleid ühendab üldjuhul veendumus, et maailma on allutamas salaja tegutsev kasuahne korrumpeerunud (paljudes tõlgendustes ka implitsiitselt kuritahtlikuna tajutud) eliit, kelle eesmärk on allutada kogu maailm oma üleilmsele autoritaarsele režiimile, mistõttu kaovad kõige muu püha ja väärtusliku hulgas ka rahvusriigid. Hübriidse paremäärmusliku võrgustiku erinevad sõlmekesed jagavad väga süstemaatiliselt linke teistele ideoloogiliselt seotud grupuskulitele, aga ka ametlikele parempopulistlikele struktuuridele, nagu erakonnad, seltsid, klubid.

\section{Grupuskulite enesekirjelduse tasand}

Paremäärmusliku online-kommunikatsiooni ja sealsete väärtushierarhiate kujunemise loogikate selgitamiseks on oluline leida sobilik kirjelduskeel. Roland Barthes'i järgi on interdistsiplinaarsuse lätteks ennekõike vanade teaduskeelte jõuetus maailma mitmekesisuse seletamisel, mitte aga lihtne eripalgeliste distsipliinide liitmine (Barthes 1977: 155). Käesoleva artikli autorite arvates täiendab kultuurisemiootiline lähenemine tänapäevase paremäärmusluse analüüsimise vahendeid, pakkudes selle fenomeni uurimiseks ka korrastatud metakeele. Siinkohal on oluline Griffini sedastus, et grupuskuli mõiste kaudu saab avada tänapäevase, hüpermeedia keskkonnas aktiveerunud paremäärmusluse organiseerumis- ja kommunikatsiooni loogikat (Griffin 2002: 4). Pidades silmas sissejuhatuses püstitatud põhiküsimust - kuidas paremäärmuslikes grupuskulites vastandlikest väärtushinnangutest lähtuv enesekirjeldamine üles ehitub - kontseptualiseerime grupuskulit semiootilise üksusena, mille eneseteadvuse (ehk enesekirjelduse) metatasandil eraldavad erinevaid sfääre piirid. Enesekirjeldus on üks universaalsemaid semiootilisi operatsioone, mille käigus toimub oma spetsiifika teadvustamine ja enese vastandamine muudele, n-ö välistele sfääridele (Lotman 1999: 16). Seejuures tuleb rõhutada, et enesekirjelduse metatasandile tõusmine nõuab alati mingisse laiemasse kultuuriühtsusesse kuulumist. Ainult suurema terviku osana saab semiootiline üksus omandada enda suhtes välise vaatepunkti, mis võimaldab end ainulaadsena tajuda (Lotman 1999: 33). Nagu märgib Griffin, võivad grupskuskulite füüsilised manifestatsioonid olla põhimõtteliselt erinevat laadi: veebilehed, ajakirjad (Griffin 2002: 4), aga ka paremäärmuslikke vaateid jagavate inimeste põrandaalused koosolekud. Niisuguseid hajusaid grupuskuleid konstitueerib teatav ideoloogiline samastumine ning sarnaste retooriliste mallide repertuaar, 
mitte aga neid ümbritsev info-ja kommunikatsioonitehnoloogiline keskkond. Sünteesides Griffini tähelepanekuid kultuurisemiootika mõistetega, saame eksplitseerida konkreetsete paremradikaalsete sõlmekeste enesekirjeldusi, aga ka nende suhestamist teiste paremäärmuslike grupuskulitega ning online-sfääri kui tervikuga; kusjuures kõiki märgitud tasandeid iseloomustab vastastikune sõltuvus.

Enesekirjeldusprotsessid tagavad semiootiliste üksuste seesmise korrastatuse ja ühtluse, ning aktiivses vastastoimes perifeeria loomupärase ebaühtlusega loovad enesekirjeldusprotsessid dünaamikat (Lotman 1999: 18). Seega loob grupuskulite enesekirjeldus teatavad raamid, mis piiritlevad tänapäevase paremäärmusliku tähendusloome võimalikke horisonte. Samas: just piiride markeerimise käigus muude grupuskulitega, teiste alternatiiv- või peavoolumeedia esindajatega kogu kommunikatsiooniruumis kui tervikus, luuakse tingimused interaktsiooniks, ideede vahetuseks ning transformeerimiseks. Nii jagab suurem osa paremäärmusliku võrgustiku sõlmekesi ühiseid ideoloogilisi arusaamu. Griffin (2011: 69) on osutanud, et paremäärmuslikul grupuskulaarsel väljal tuntakse läbivalt hirmu näiteks kultuurilise homogeniseerumise ja massilise migratsiooni ees, kuid samas on paljud sõlmekesed rahvusliku taassünni ideoloogiat nii põhjalikult transformeerinud, et selle kese (mure rahvusliku allakäigu ja taassünni pärast) on peaaegu äratundmatu.

Pierre-André Taguieff (1999) toonitab, et tänapäevane paremäärmuslik diskursus on hakanud märkimisväärselt transformeeruma. Traditsiooniliste rassismi vormide diskrimineeriv loomus, mis hoiab alal rassilise domineerimise hierarhiat, taandub tänapäeval vähem ilmse diferentsiaalse rassismi ees, mille peamiseks mureks on oma identiteedi unikaalse ja puhtana hoidmine. Diferentsiaalse rassismi idée fixe on oma eripärade kujutamine kaduva ja ohustatuna, usutakse, et toimub rühmaidentiteedi kustutamine. Nihe hierarhiast diferentseerumisse väljendab muresid, mis seostuvad peamiselt oma identiteedi väljendamatuse, kõrvutamatuse ja võrreldamatusega. (Taguieff 1999: 210.) Sellise tendentsi ilmestamiseks võib eesti paremäärmuslikest blogidest tuua postituse, mis räägib Nizza Põhiõiguste Harta ohtlikkusest rahvuslusele ja moraalitundele, pikemalt keskendutakse 21. ja 22. artiklile:

Kultuuriline, usuline ja keeleline mitmekesisus käsib austada kultuurilist, religioosset ja keelelist erisust (mitmekesisust). Selle võrdsustamise kaudu avatakse tee multikultuursusele ja seega nende nii religioossete kui ka kultuuriliste identiteetide desintegratsioonile, mis peaksid kuuluma pigem kaitse alla (http://rahvuslane.blogspot.com/2011/07/euroopa-liitvahend-relativismi.html). 
Selles tsitaadis apelleeritakse erinevate religioossete ja kultuuriliste identiteetide kaitsmise vajadusele. On tähelepanuväärne, et paremäärmuslik blogi mingis mõttes justkui tunnustab teiste identiteetide olemasolu ja säilitamise vajadust. Varasema teise hävitamise asemel püüeldakse nüüd enese säilitamise poole. Ennekõike rõhutatakse, et ollakse huvitatud unikaalse kultuurilise identiteedi kaitsmisest. Rassile ei pruugitagi otseselt vihjata, sellele võidakse valgust heita hoopis osutades religioonile, rahvusele, kultuurile, päritolule, stiilile, mis toimivad enam-vähem sünonüümidena (Gilroy 1992). Sageli räägivad paremäärmuslased oma pühast, kuid ohustatud rahvusest, mida on vaja vaenulike võõrmõjude eest päästa. Samas jäädakse tihti hätta oma ja ohustatut konstitueerivate tunnuste määratlemistel ning selleteemalistes selgitustes kaldutakse ennekõike essentsialistlikusse rahvuse käsitlusse. Meie vaadeldud blogipostitustes tunti läbivalt muret sellepärast, et põliseestlus on kohutava kiirusega hääbumas. Peamiste ohuteguritena toodi välja eestlastele omase kristliku moraalitunde ja talupojatarkuse asendumine naiivse kõigesallimise ja rahaeetikaga; Eestimaa müümine välismaalastele; isamaa-armastuse süstemaatiline naeruvääristamine. Kujukaks näiteks oma identiteedi ohustatuse ning kaitsmise vajaduse tunnetamisest pakub järgmine postitus:

Euroopa rahvusriike ähvardab hädaoht. Meile, oma maa patriootidele, öeldakse, et me oleme kitsarinnalised. Meid süüdistatakse vihkamises. Meid ähvardatakse vanglate ja ümberkasvatamisega. Meist on tehtud 21. sajandi ketserid. Sellele vaatamata tõotame me jä̈̈da iseendaks, sest rahvuslus on tuhat korda parem kui multikultuursus, sest meie maa ja rahvus on meile kallim kui raha ja võim, sest oma riigi teenimine, mitte sulandumine juurteta massi on meie jaoks tõeline vabadus, ja sest meie esivanemate pärandus teeb meid tugevamaks kui globalistide mesijutud. Ärgake, Baltimaad! Atmostas Baltija! Bunda jau Baltija! (http://rahvuslane.blogspot.com/2013/11/baltimaade-isamaalised-nooredeuroopa.html)

Seejuures väldivad paremäärmuslased sageli oma seoste markeerimist selget sotsiaalset stigmat kandvate ideoloogiatega (fašism, natsism) ning nende diskursus on motiveeritud eelkõige "lugupidavuse" esilekutsumisest (rõhutatakse kogukonda, identiteeti, samas separatismi-tungi rõhutavat ideestikku eriti ei eksplitseerita (Atton 2006: 576). Eesti paremäärmuslust käsitlevad uurimused on osutanud, et siinne rahvusradikaalne diskursus on viimastel aastatel olulisel määral mahenenud, näiteks on vähemaks jäänud otseseid üleskutseid vihakuritegudele, samuti ei ole enam väga levinud üldtuntud natsisümboolika kasutamine (KaPo 2012: 4; Siibak 2012). 
Paremäärmuslased jagavad sageli vasakradikaalidega vaenlasi, kelleks võivad olla näiteks suhteliselt abstraktsed globaliseerumine, kapitalism, rahvusvahelised firmad, USA (vt Sommer 2008: 313-314). Samuti võib mõni paremäärmuslik liikumine toonitada keskkonnateadlikkust, mille kaudu kritiseeritakse tänapäeva läänemaailma progressikultust (Griffin 2008: 196). Tõsi, paremäärmuslased ei vastandu globaalsele kapitalismile üldjuhul mitte selle tekitatud majandusliku ebavõrduse ja vaesuse tõttu, vaid eelkõige seepärast, et tajutakse, et see ohustab etno-natsionalistliku homogeense ühiskonna ideaali ning seostub juutide poolt kehtestatud salajase uue maailmakorraga (Sommer 2008: 313-315). Teise konstrueerimisel rõhutatakse peamiselt multikulturalismist tulenevaid ohtusid. Valget rassi (ingl Whiteness) tajutakse ka globaalses mõttes ohustatuna, mistõttu tunnetatakse, et valged on uus minoriteet (Back 2002b: 638). Valge rassi diskrimineerimise ja programmilise hävitamise teema on läbiv ka meie uuritud blogides, vahel osutatakse, et vaenatakse ka neid, kes ei kuulu seksuaalvähemusse, näiteks kirjutatakse:

LOODE ÜLIKOOLI KANDIDAAT BLOKEERITI, SEST ON HETEROSEKSUAALNE VALGE MEES. Ta oli liiga normaalne, et neile meeldida. USAs on ammu pingutatud etnomasohhistide poolt, et hävitada valge rass kui selline. (http://nsblogi.com/2013/05/19/absurdism-levib/)

Nagu artikli alguses osutatud, iseloomustab Les Back (2002a, vt ka Atton 2006: 574-576) tänapäevast paremäärmuslust terminiga voolavad ideoloogiad (ingl liquid ideologies): see aitab selgitada eelpool kirjeldatud suundumust, kus üldaktsepteeritud diskursuse (nt osalusdemokraatia, sõnavabaduse, võrdõiguslikkuse jne) elemente assimileeritakse etnotsentristlikeks meediapraktikatesse, et viimastele legitimeeritust lisada. Nii kohandub paremradikaalne meedia näiteks multikulturalismi diskursuse keelega, laenates sealt tuummõisted, nagu võrdsus, õiglus, õigused ning viib need ekvivalentsus-suhetesse natsionalistliku diskursuse elementidega, millega nad pealtnäha tunduvad täiesti kokkusobimatud.

\section{EI ACTAle kui diskursust koondav tühi tähistaja}

Les Backi voolavate ideoloogiate põhimõte iseloomustab ka meie vaadeldud paremäärmuslikku veebisuhtlust, mis reflekteeris ACTA ratifitseerimise küsimuse üle Eestis. ACTA temaatika avamisel põimiti kokku nii demokraatia ja võrdõiguslikkuse sõnavara (sõnavabadus, õiglus, võrdsus jne) kui ka rassismi ja ksenofoobiat tähistavad elemendid. Järgnevalt selgitame veebisuhtlust kultuurisemiootika ja Essexi koolkonna hegemooniateooriast lähtuvalt. 
Sotsiaalse ja poliitilise reaalsuse küsimus taandub Laclau silmis diskursuse konstitueerimise küsimuseks. Laclau järgi tuleks hegemooniat mõtestada üksnes diskursuse pinnal: hegemooniline suhe pole midagi muud kui teatud tähenduste liigendus (Laclau 2006: 114). Selle tähistamisprotsessi spetsiifiliseks tunnuseks on samaväärsusloogika prevaleerimine erinevusloogika üle, retoorikatermineis vastab esimene metafoorilisele ja teine metonüümilisele artikulatsioonitüübile. Hegemooniline tähistamisloogika koondub ümber ühe konkreetse tähistaja, mida Laclau (1996) nimetab tühjaks tähistajaks. Viimane omandab tähistamissüsteemis ehk diskursuses domineeriva positsiooni, allutades enesele rohkemal või vähemal määral kõik muud diskursuse liikmed, lastes neil paista samaväärsetena ning õõnestades nende omavahelist erinevust (Laclau 2002). ACTA ratifitseerimisega seotud diskursuse juures kujunes niisuguseks keskseks domineerivaks tühjaks tähistajaks EI ACTAle. Leping, mille eksplitseeritud eesmärk oli peaasjalikult intellektuaalsete omandisuhete reguleerimine, muutus suure osa protestijate (ja oluline on rõhutada, et paremäärmuslased moodustasid siin üksnes väikese osa) silmis juriidiliseks seadustikuks, mille ratifitseerimises nähti ohtu ennekõike sõnavabadusele ning sellest lähtuvalt ka kogu demokraatlikule ühiskonnakorraldusele. Antud suundumusest annab tunnistust järgmine postitus, milles osutatakse Eesti põhiseadusega kaitstavatele väärtustele ja ACTA põhimõttelisele vastuoksusele demokraatliku põhikorraga:

Nõustuda tuleb, et intellektuaalomand on ühiskonnas oluline ja vajab kaitset, kui samas ei tohiks seda seada ülemaks isiku põhiõigustest eraelu puutumatusele, väljendusvabadusele ja andmekaitsele ning muudest õigustest, nagu sü̈̈tuse presumptsioon ja tõhus kohtulik kaitse. Seega leiame, et demokraatlikult ühiskonnale ebaomaselt läbiräägitud ACTA ei saa olla tänasel kujul sobiv meie õiguskorda, mistõttu palume kõigil anda enda hääl ACTA vastu ning koos võime suuta mõjutada ka Eesti riiki enda sõna ütlemisel. Anna allkiri siin: http: / / petitsioon.ee / ei-actale. (http://rahvuslane.blogspot.com/search?q=acta)

Antud postituse juures on oluline, et EI ACTAle koondab lisaks sõnavabaduse kadumise murele oma diskursusesse veel teisi tähistajaid, nagu eraelu puutumatus, andmekaitse jne. Selge, et need tähistajad osutavad oma partikulaarsuses erinevatele sisudele, kuid käesoleval juhul on nad ühe tähendusliku diskursuse liikmed, mida koondab ACTA-vastasus ja mille diskursusesiseseks dominandiks on kujunenud oht sõnavabadusele. Seejuures suunatakse grupuskulis lingile, mida kasutatakse Eestis avalike petitsioonide foorumina (www.petitsioon.ee), ning osutatakse suurimale Eesti päevalehele Postimees, mille teatel kanti Tallinnas ja Tartus järgmisi loosungeid: 
"I love my country, but fear my government", "No ACTA, no new world order", "1984 - Orwell was only off a decade or two", "ACTA - globaalne tsensuur", "Stop ACTA - enne kui ruum otsa saab” ja Tartust teatas DELFI meeleavaldajatest plakatitega: “"Stop ACTA!”, “ACTA=nuhkimine”, "ACTA on põhiseaduse vastane”, "ACTA on E-ühiskonna lõpp”, "ACTA võrdub Molotov-Ribbentropi pakt”, “Sure põrgus ACTA!”, jne (http:// rahvuslane.blogspot.com/search?q=acta).

Sarnast tähistamisloogikat, mis seab samaväärsetena ritta erinevad tähistajad, näeme ka teiste postituste juures:

Nagu selgub, on teatud kontingendile lubatud esineda sotsiaalvõrgustikus poliitiliste vaadetega ja osadel mitte. Näiteid võib tuua suure lombi tagant (nt. president Obama selge reklaam-ja poliitpropaganda kasutaja) aga ka kodumaalt. On ju enamikel poliitilistel liikumistel ja institutsioonidel oma veebileht ja facebooki kasutaja. Reformierakond, Keskerakond, Eestimaa Rohelised, president Toomas Hendrik Ilves, Ei ACTA-le, Meeleavaldus valeliku ja ülbe poliitika vastu jne. Poliitiline aktiivsus teatud piirides ja eelnevalt heaks kiidetud liidrite juhtimisel on lubatud - aga mitte grammigi rohkem! (http://www.vabamotleja.info/index.php/poliitika/73facebook-keelustab-poliitiliselt-ebakorrektseid-pilte)

Käesoleva postituse puhul märkame juba selgemalt paremäärmuslikule grupuskulaarsele kommunikatsioonile omast vastandumist poliitilisele ja majanduslikule eliidile, kusjuures ei puudu ka negatiivne suhtumine globaliseerumist signeerivasse Ameerikasse (President Obama...), aga ka Euroopa Liitu kui viimase vasalli (järgmises lõigus jutumärkides eesrindlik Euroopa riik). Poliitilist aktiivsust on siin mõistetud demokraatia ühe põhiväärtuse - sõnavabaduse rõhutamise kaudu. Samas tajutakse, et eliit on sõnavabaduse monopoliseerinud ning tõkestab endale ebasoodsate vaadete levitamist: teatud kontingendile lubatud esineda sotsiaalvõrgustikus poliitiliste vaadetega ja osadel mitte; poliitiline aktiivsus teatud piirides ja eelnevalt heaks kiidetud liidrite juhtimisel on lubatud. Sõnavabaduse piiramise peamise eesmärgina nähakse asjaolu, et võimueliiti ohustab alternatiivsete (käesoleval juhul paremäärmuslike) häälte jõudmine laiema auditooriumini, kuna see võiks tekitada massirahutusi ning viia olemasoleva dekadentliku korra kukutamiseni. Usutakse, et aktiivsetele kodanikele, kes sõnavabaduse piirangutest teadlikult üle astuvad, toob see kaasa üsna karmid riigipoolsed (valitsejate läbi surutud) meetmed:

30. juulil saatis justiitsministeerium kooskõlastusringile eelnõu, mille kohaselt on võimalik karistada rahatrahviga või kuni kolme aastase vanglakaristusega inimest, kes tegeleb süstemaatiliselt või avalikku 
rahu häirival viisil "vihakuritegevusega", s.o. nn vaenu õhutamine $k a$ juhul, kui sellega ei põhjustata ohtu kellegi elule, tervisele või varale. Ei, see ei ole nali ja ei, ma ei parafraseeri George Orwelli raamatut "1984". Just säärane seadusemuudatus kavatsetakse läbi viia, et olla "eesrindlik Euroopa riik”. (http://www.vabamotleja.info/index.php/poliitika/74paragrahv-151-ehk-suukorv-paehe)

Teisalt on selge, et niisuguses tähistamisprotsessis hakkab iga partikulaarse tähistaja (ehk diskursusesse kuuluva elemendi) sisu tühjenema, sest nii sõnavabadus, eraelu puutumatus, kodanike poliitiline aktiivsus ning andmekaitsealane ja laiem juriidiline diskursus ei ole üksteisele taandatavad. Neil kõigil on üksikuna või teistesse diskursiivsetesse kontekstidesse asetatuna erinev tähendus. Samas, nagu rõhutab Laclau, saavutatakse paradoksaalsel moel sellise õõnestamise kaudu teatud ühtsus või läbipaistvus (süsteemsus): EI ACTAle funktsioneerib siin diskursust koondava ja kehastava tühja tähistajana. Selle tähistaja tühjenemine ilmneb järgmise loogika kaudu: olles tähistamissüsteemi (tähenduslikku ja terviklikku diskursust) kehastaval positsioonil, tühjeneb see enim oma esialgsest sisust, milleks oli ennekõike juriidiline intellektuaalse omandi reglementatsioon. Alles nüüd hakkab ta kehastama teataval viisil selle diskursuse kõiki partikulaarseid tähistajaid, olles ühtlasi piiriks, mis eristab teda teistest diskursustest.

Oluline on rõhutada, et see ületamatu pinge erinevus-ja samaväärsusloogika vahel on iga diskursuse jaoks konstitutiivne, võimaldades tähendusliku diskursuse tekkimist. Samal ajal on see ka ebapüsiv, kuna iga diskursus on oma protsessuaalse loomuse ja teistele sarnastele diskursustele pidevate vastandumiste tõttu ajutine. See, milline tähistaja kogu diskursust konstitutiivselt kehastama hakkab, on kontekstispetsiifiline ja teataval määral ennustamatu. Tuleb silmas pidada, et diskursuse moodustamine ei tulene mingist metafüüsilisest alusest ega ette-antud struktuurist. Niisuguse tähendusliku ühtsuse loomine saab olla üksnes figuraalne või tropoloogiline konstruktsioon (Laclau 2006: 114).

\section{E-Eesti kui enesemudel}

Laclau järgi on liikumine ühest hegemoonilisest formatsioonist teise alati radikaalne murrang, n-ö loomine ex nihilo. Tema sõnul ei moodustata diskursust täiesti uutest elementidest, küll aga tuletab diskursuse nimi ehk tühi tähistaja, mille ümber uus tähenduslik diskursus konstrueeritakse, oma keskse rolli uuest loogikast lähtuvalt (Laclau 2005: 228). Siinkirjutajate arvates seab niisugune sattumuslikkuse rõhutamine teatavad piirangud konkreetsete poliitiliste si- 
tuatsioonide analüüsimisele. Tundub, et saame seda käsitlust kultuurisemiootika abil täiendada, eriti otstarbekaks osutub siinpuhul enesemudeli mõiste. Enesemudel, nagu öeldud, funktsioneerib semiootilise süsteemi abstraktsel tasandil, "mille abil tuvastatakse kultuur selle unifitseeritud, kunstlikult skematiseeritud, struktuurse ühtsuse tasemeni viidud kujul" (Lotman \& Uspenski 2013a: 235).

Käesoleva teemaga seotult on oluline märkida, et tuleb eristada kahte tüüpi tekste. Enesemudel kuulub põhimõtteliselt teisele tasandile kui kommunikatsioonis ringlevad tekstid, mida selle enesemudeliga dešifreeritakse (Lotman 2010: 64). Seega, uurides grupuskulite enesekirjeldusi tuleb meil selgelt eristada kahte tasandit: a) esmast tasandit ehk paremäärmuslaste konkreetseid postitusi ja tekste, mida erinevates kommunikatsioonisituatsioonides toodetakse; ning b) teisest ehk metatasandit, mille kaudu grupuskulid ennast ja enda loodud tähenduslikke diskursusi või tekste refleksiivselt mõtestavad ja kirjeldavad, ehk seda, milline on nende ideaalpilt endast. Samas, nagu osutavad Lotman ja Uspenski, avaldab enesekirjeldamisvajadus, mis on seotud tarvidusega luua endast teatud etapil väärtuste- ja struktuuripõhine tervik, kultuurile kui kirjeldatavale fenomenile jõudsat mõju (Lotman \& Uspenski 2013b: 241). Loomulikult on erinevatel kultuuri metakirjeldustel varieeruv potentsiaal muutuda objektkeele osaks ja seda transformeerida. See sõltub mitmetest ajaloolistest ja sotsiokultuurilistest teguritest. Pealegi saab enesekirjeldust eelnevast seisundist eristada üksnes teoreetiliselt, sest tegelikkuses mõjutavad need kaks seisundit teineteist vastastikku (Lotman \& Uspenski 2013b: 241). Seega on oluline märkida, et keskendume artiklis sellele, kuidas erinevate enesekirjelduslike metamudelite kooseksisteerimine toodab tekstide (ehk esmasel) tasandil pealtnäha paradoksaalseid ideoloogilisi kombinatsioone.

Eesti paremäärmuslaste enesekirjelduslikku metamudelit ei saa vaadelda lahus Eesti avalikus ruumis toodetavast e-diskursusest, mida võib iseloomustada kui näidet Dominic Boyeri kirjeldatud küberneetilis-informatsioonilisest epistemoloogiast, mis on omane online-meedia sisuloojate enesekirjeldustele. See väljendub eelkõige samastumises hüpermeedia põhitunnustega (mitte-hierarhilisus, dünaamilisus, detsentraliseeritus, interaktiivus). Kusjuures osutatud kvaliteetidele omistatakse kõrge aksioloogiline väärtus, neid väljendatakse eelkõige puhkudel, mil soovitakse esile tuua oma meediapraktikate progressiivsust vastandatuna n-ö traditsioonilistele (Boyer 2010: 79-80). Interneti suhteline anonüümsus rassi, usutunnistuse, klassi, religiooni, soo, asukoha jne suhtes ning detsentraliseeritust ja interaktiivsust soodustav loomus on paljude silmis märk meediumi demokraatlikkusest. Dean Ballingeri järgi koondub selline küberdemokraatia diskursus valdavalt kättesaadavuse ja interaktiivsuse kui kahe müüdilise tuumtähistaja ümber. Kättesaadavus tähendab antud kontekstis, 
et aktiivsetel kodanikel on tänu uuele informatsioonikeskkonnale võimalik ületada kõiksugu aja, raha, energia ja geograafilise asukoha seatud piiranguid ning osaleda ühiskondlikke probleeme puudutavas arutelus. Interaktiivsus aga eelkõige seda, et hüpermeedia tingimused soodustavad ühiste huvidega inimeste organiseerumist (Ballinger 2011: 125-126). Seetõttu tähendustatakse internetti sageli alternatiivse avaliku sfäärina, kus aktiivsetel kodanikel on seninägematud võimalused organiseerumiseks ning ühiskondlikes aruteludes kaasarääkimiseks.

Selline küberdemokraatia diskursus on saavutanud eestlaste identiteediloomes iseäranis olulise koha. Meile meeldib mõelda Eestist kui e-riigist, kus tänu nutikatele digilahendustele on välja kujunenud sild võimuinstitutsioonide ja rahva vahel. 2013. aasta kevadel kokku kutsutud ning väga laia kõnepinda leidnud Rahvakogu on selle kujukaks näiteks. Üldiselt kannab kõik interneti ja digilahendustega seonduv eestlaste silmis ülipositiivset laengut: selles nähakse lisaks demokraatia võimaluste avardumisele ka tulevikku suunatust, vabadust, progressi. Eestlastele meeldib end presenteerida kui riiki, mis on küll väike oma pindalalt ja rahvaarvult, ent paistab ometi maailmaareenil silma võimsa küberriigina. Oleme uhked, et tiigrihüppega üles kasvanud põlvkond on saanud tööealiseks ning rikastab kodumaad innovaatiliste IT-lahendustega (nt Skype). Meile meeldib end reklaamida e-Eestina: äärmiselt edumeelse ja edasipüüdliku riigina, kus isegi metsades levib internet. Tunneme uhkust selle üle, et saame e-hääletada ja digiretseptiga ravimeid osta, et just nimelt Eestis asub NATO küberkaitsekeskus jne. Niisiis on e-diskurus, mis kihab suurema või väiksema intensiivsusega kogu ülemaailmsel areenil, eestlaste meeltes ümbritsetud iseäranis tugeva väärtuslaenguga. Seetõttu on mõistetav ka ACTAga seonduv üldine pahameel, sest paljud nägid ACTAs oma identiteedi positiivsete ning tulevikku suunatud põhiväärtuste õonestajat.

Kahtlemata on sellisel küberneetilis-informatsioonilisel diskursusel oluline roll ka paremäärmuslike grupuskulite enesekirjelduslike mudelite sõnastamisel. Eesti paremäärmuslased näevad e-Eesti edulugu kui rahvuslikku uhkust, kui midagi, mis tõestab eestlaste erakordset innovatsioonimeelsust, töökust ja digiahenduste alast taibukust, mis tuleb kujukalt esile teiste rahvuste taustal (http://rahvuslane.blogspot.com/2014/01/skype-kuberturbemeeskonnajargi-nuhiti.html). Samuti mõtestavad paremäärmuslike blogide autorid end radikaalsete kodanikuajakirjanikena. Grupuskulite enesekirjeldustes kujutatakse end peavoolu meediale vastanduva alternatiivse kontrakultuurilise avalikkusena, kes on teostamas (tänu hüpermeedia vahenditele võimalikuks saanud infovabaduse) revolutsiooni, mille põhieesmärk on kõigutada riigiaparaadi huve teenivaid objektiivsuskaanoneid ning üldisemaid liberaaldemokraatlikke väärtusi. Oma tegevuse (blogipidamine, petitsioonide organiseerimine, 
kommentaaride kirjutamine jne) ja ideede (kõigil on õigus oma veendumusi sõnastada ja levitada) essentsiaalse demokraatlikkuse rõhutamine võimaldab nii paremäärmuslike rühmituste endi kui ka laiema üldsuse silmis legitimeerida hüpermeedia tingimustes aset leidvat ideedevahetust. Osutatud suundumus näitab, et tänapäevane paremäärmuslus ei eksisteeri omaette suletud sfäärina, vaid oma ideede ja väärtuste sõnastamisel ollakse pidevas interaktsioonis peavoolukultuuris domineerivate diskursustega. Enesekirjelduslik mudel funktsioneeribki kõige üldisemalt võttes konkreetse terviku, käeoleval juhtumil grupuskuli, tekstide enesetunnetuse ja -dešifreeringu koodina. Seetõttu ei ole põhjust imestada, et ühe blogi avalehel võib lugeda lõiku Eesti Vabariigi konstitutsioonist:

'Igaühel on õigus vabalt levitada ideid, arvamusi, veendumusi ja muud informatsiooni sõnas, trükis, pildis või muul viisil. Seda õigust võib seadus piirata avaliku korra, kõlbluse, teiste inimeste õiguste ja vabaduste, tervise, au ning hea nime kaitseks. Seadus võib seda õigust piirata ka riigi ja kohalike omavalitsuste teenistujatel neile ameti tõttu teatavaks saanud riigi-või ärisaladuse või konfidentsiaalsena saadud informatsiooni ning teiste inimeste perekonna- ja eraelu kaitseks, samuti õigusemõistmise huvides. Tsensuuri ei ole.' Aga tegelikult?! (http://rahvuslik.blogspot.com/)

Eelpool toodud näidetest tuli välja, et paljuski kattub paremäärmuslaste võimudevastane kriitika laiema, n-ö uue põlvkonna kodanikuühiskonna retoorikast võrsunud kriitikaga. Grupuskulaarsetes enesekirjeldustes funktsioneerib struktureeriva koodina enesemudel, mis on koondunud väärtusmõistete (sõnavabadus, eraelu puutumatus jne) ümber. ACTA ratifitseerimist seostatakse nende väärtuste ohustamisega. Teisalt aga esinevad grupuskulaarses kommunikatsioonis koos nimetatud väärtustega ka nendega ilmselgelt vastuollu minevad tähistajad. Vaatame EI ACTAle ümber konstrueeritud paremäärmuslikku diskursust lähemalt.

\section{Paremäärmuslik sõnavabadus}

Viimati esitatud Eesti Vabariigi konstitutsioonist kopeeritud lõigu lõpus osutas küsilause "Aga tegelikult?" eliidi juhitud riigi näilisele demokraatiale ning probleemidele, mida niisugune silmakirjalikkus kaasa toob. Paremäärmusliku diskursuse vandenõuteoreetilisele tõlgendamisloogikale (vt ka järgmises lõigus 
sõnakasutusi "paistab”, “üldiselt teada...", “tõenäoliselt”) kohaselt usutakse, et siinne (Eesti) eliit on kõigest üks osa suuremast kuritegelikust jõust, mis koondab nii globaalset poliitilist, aga ka majanduseliiti, peavoolumeediat, mitmesuguseid vähemusrühmasid, salaühinguid jne. ACTA seostest üleeuroopalise konspiratsiooniga kõneleb ka järgmine postitus:

Nii, nü̈̈d on siis asjad selged, Euroopa Komisjon (sisuliselt EL-u valitsus) võttis lihtsalt lühikese pausi. Pettes Euroopa rahvaid, et saadab asja Euroopa Kohtusse, kuid tegelikult seda ei teinud. [...] Paistab, kõrgametnikel on ACTA kehtestamisega nii kiire, et nad ei saanud endale lubada 1,5. aastast pausi, mille kestel kohus oleks asja arutanud. On ju üpris üldiselt teada, et Euroopa Liitu juhitakse huvigruppide ja mitmete salaühingute poolt. Tõenäoliselt oli avaldatud surve nii suur, et komisjon otsustas kohtu poole mitte pöörduda. Nü̈̈d seisab aga ACTA vastastel aktivistidel ja inimestel üle Euroopa ees uus võitluslaine. (http:// rahvuslane.blogspot.com/search?q=acta)

Vastavalt päevakajaliste sündmuste muutumisele võib postitustes kohata erinevaid vaenlasi, kuid peamiselt osutatakse ikkagi Ameerika ja Euroopa Liidu korrumpeerunud eliidile ning ennekõike juutidele, kes väidetavalt sõnavabaduse piiramisest enim kasu saavad. Nii võime lugeda:

Praegu probleemiks tõusnud blasfeemiaseaduse juured on aastas 2001 kui Euroopas võeti vastu Küberkuritegevuse konventsioon (ETS185, Eesti poolt ratifitseeritud 2003). IT-kuritegude kriminaliseerimiseks oli lihtsalt aeg küps, kuid teatud jõududele näis küberteema võluvitsana muude, kahtlasemate initsiativide läbisurumisel. Sama konventsiooni prosionistlikuks peetav Lisaprotokoll ETS189 üritab jõuga kehtestada ajaloolist tõde - kriminaliseerida Holokaustis kahtlemist. Küberkuritegevuse lisaprotokoll ETS189 üritas kaht olulist muudatust: et Tõde oleks väljastpoolt määratud ja et Tões kahtlemine oleks kriminaliseeritud, et ekspertide ja teadlaste asemel määraks sü̈̈ ulatuse kannatanu "šokeerituse aste”. (http://rahvuslane.blogspot.com/2012/11/ anto-veldre-ood-blasfeemiaseaduse.html)

On näha, et niisugusel demokraatia ohustajate väljaselgitamisel on loobutud rassilise üleoleku rõhutamisest. Ennekõike püütakse näidata ennast sõnavabaduse ja demokraatia kaitsjatena. Uuritud blogipostitustes nähti sõnavabadusega manipuleerivaid antagoniste ennekõike juutides (holokausti eitamise ebaseaduslikuks kuulutamine, Iisraeli pidev kujutamine dekadentliku uue maailmakorra võimupüramiidi tipus asuvana), kuid demokraatia vaenlaste hulka arvati kuuluvat ka mitmesuguste vähemusrühmade esindajad. Sotsiaal- 
seid, majanduslikke ja etnilisi rühmi markeerivad tähistajad moodustavad omavahel diskursiivse samaväärsusahela, mille eesmärgiks on "ühiskonna suukorvistamine". Nii joonistub eesti paremäärmuslaste kommunikatsioonis välja suhteliselt püsiv vaenlase kuju: siia kuulub küll kohalik eliit, keda tajutakse alluvat Euroopa ja ennekõike Ameerika eliidile. Nagu märgitud, kujutatakse maailmaeliidi tipus enamasti juute, kelle huviks olevat monopoliseerida holokausti-tõlgendust ning läbi suruda oma kasuahnet ja amoraalset poliitikat (vt järgmine lõik "Iisrael kasutab oma oponeerijate vaigistamiseks..."). ACTAt kujutatakse paremäärmuslaste blogipostitustes vandenõulaste sepistatud protsessi järjekordse, oma kuritahtlikke kavatsusi seadusandlusse raiuva etapina:

Brüsselist on saadetud määrus ja meil ei ole enam sõnaõigust-selle oleme loovutanud Euroopa Parlamendile (jah, meil on selles oma "esindus"). Lisaks paistab fassaadi tagant veel teinegi huvigrupp, kellel on reaalselt vaheneid poliitika mõjutamiseks. Iisraeli väljaanne Haaretz kirjutab: "Raport väidab, et need kes Euroopas juute ründavad, kasutavad oma tegude õigustamiseks Iisraeli ja tema poliitika-vastast kriitikat. Kas ei oleks mõeldav (loogiline), et Iisrael kasutab oma oponeerijate vaigistamiseks ja enese õigustamiseks "vihakuritegude" siltide loopimist? Muidugi mängivad rolli ka homoaktivistid ja feministid, aga nende osatähtsus Eesti poliitmaastikul on siiani veel liialt väike, et reaalselt poliitikakäiku mõjutada. (http://www.vabamotleja.info/index.php/ poliitika/74-paragrahv-151-ehk-suukorv-paehe)

Niisuguse suukorvistamise reaalseid mõjusid kujutades konstrueeritakse juudi salaseltsi ja nende otseste või kaudsete abiliste (seksuaalvähemuste jt vähemusrühmade, moraali-ja rahvustundeta inimeste) huvidele alluv orwellik maailm:

[...] homoseksualismi pooldajad seevastu saavad oma agressiivset tänavareklaami rahulikult edasi pidada. Reklaamitavale Tõeseisukohale vastutöötamine loetakse “avaliku rahu häirimiseks”, Lehtsaare ja Põderi blogid 5 kõrvaldatakse internetist. Sinimägede kokkutulek jääb ära, sest vene sõjaveterani poeg on toimumise vaidlustanud Vaivara Sillakohtus. Auschwitzis hukkunute arvus kahtlemise eest deporteeritakse Saksamaale nagu Ernst Zündel ${ }^{6}$ ja määratakse 5 aastat vangistust. Huvitaval kombel vene Gulagist tohib endiselt rääkida. Gaasikambrite võimaliku konstruktsiooni ja tootlikkuse üle arutlemine on keelatud isegi teadustöödes. (http://rahvuslane.blogspot.com/2012/11/anto-veldre-oodblasfeemiaseaduse.html)

Käesoleva näite puhul on tähelepanuväärne, et paremäärmusliku maailmavaate legitimeerimiseks kaasatakse positiivsesse enesekirjeldusse ka kristlik 
väärtussüsteem, sest Lehtsaare ja Põderi blogidest, millele mitmed postitused osutavad, leiame homoseksuaalsuse vastaseid sissekandeid põhjendatuna just piibellikust interpreteeringust lähtuvalt:

Kas võib meid ees oodata aeg, mil vaimulik pannakse kolmeks aastaks vangi süsteemse viha õhutamise eest jumalateenistustel? On ju piibel homoseksuaalide suhtes üsna sallimatu! "Ära maga meesterahva juures nagu magatakse naisterahva juures, sest see on jäledus!” (http://www. vabamotleja.info/index.php/poliitika/74-paragrahv-151-ehk-suukorvpaehe).

Niisugune püsiv hierarhia (kohalik eliit, kes allub Euroopale, viimane aga on omakorda allutatud juutide ja Iisraeli poolt juhitud Ameerika poliitikale) osutab eesti paremäärmuslike grupuskulite kommunikatsiooni aluseks olevale ja seda teataval viisil konstitueerivale enesemudelile. Sarnast hierarhiat kohtame ka teiste postituste juures, mis pole analüüsitava ACTA juhtumiga otseselt seotud. Seega ei saa niisugust enesemudelit pidada radikaalselt sattumuslikuks: need tähistajad ise kuuluvad kindlapiirilistesse ja rahvuse alusel määratletud struktuuridesse.

See, millised tähistajad konkreetses diskursuses domineeriva positsiooni saavad, sõltub paljuski kontekstuaalsetest sündmustest, mis paremäärmuslikku tekstiloomet aktiveerivad. Näiteks Snowdeni ja PRISMi skandaali paremäärmuslikus retseptsioonis on sõnavabadus suuresti asendunud eraelu puutumatusega. Ühes postituses märgitakse:

Tõelised vabaduse- ja rahvakangelased nagu Bradley Manning, Julian Assange ja Edward Snowden riskisid aga kõigega ning olid sunnitud tsivilisatsiooni eest täielikult pakku pugema, kuna Suur Vend ei tunne und ja on pea kõikjal. Totaalne kontroll inimeste üle hakkab aina enam ja enam päevavalgele jõudma. (http://rahvuslane.blogspot.com/2013/10/ telegrami-lugeja-avalik-kiri-eestile-v.html)

Nii paremäärmuslaste postitused kui ka peavoolumeedia arvamuslood olid suuresti kantud murest privaatsuse kadumise ning kontrollimatu jälgimise ees, väga sageli mõtestati NSAga seonduvat Orwellilt laenatud kujundite kaudu.

$* * *$

Käesoleva juhtumi analüüsimisel joonistus diskursuse tasandil välja kaks abstraktset ja hierarhiliselt struktureeritud enesemudelit: a) enesemudel, mille dominandiks oli sõnavabadus ja b) enesemudel, mis tugines (peamiselt) juutide 
poolt vaikima sunnitud natsionalismile. Osutatud enesemudelite puhul on tähelepanuväärne, et eraldi võetuna väljendasid nad üksteisele selgelt vastanduvaid väärtussüsteeme, kuid konkreetse diskursuse tasandil moodustasid teatava ühtsuse. Sellist vastandlike enesekirjelduslike tuumade sidumist võimaldas vastandumine ACTAle.

Eesti paremäärmuslikus veebisuhtluses väljendati oma ideoloogilisi seisukohti nii-öelda topeltsuunatuse kaudu: ühelt poolt rõhutati sõnavabadust, mida ACTA ohustas. Sõnavabaduse rõhutamine oli ennekõike vajalik selleks, et oma paremekstremistlikke vaateid legitimeerida, tegemist oli n-ö väljapoole suunatud kommunikatsiooniga. Lotmani järgi tugineb igasugune kultuuriline kommunikatsioon kahele üksteist täiendavale mehhanismile, mida võib analüütilisel tasandil kirjeldada kui autokommunikatiivset mina-mina süsteemi ja kommunikatiivset mina-tema süsteemi. Mina-tema kommunikatsioonisüsteemis jääb edastatava informatsiooni hulk samaks, suureneb üksnes info teadjate hulk (adressant vahetab välja adressaadi), kuid teade ise ja kood, milles on antud teade üles ehitatud, jäävad samaks (Lotman 2010: 129). Grupuskulaarses kommunikatsioonis, kus keskendutakse peamiselt sõnavabaduse rõhutamisele, on tegemist n-ö väljapoole suunatud kommunikatsiooniga, mille eesmärgiks on oma seisukohtade edastamine ja ühisosa leidmine teiste alternatiivsete häältega. Seejuures püütakse sõnavabaduse abil tsenseerida ja elimineerida avalikkuse teisi hääli (nt feministid, homoseksuaalide ja rahvusvähemuste õiguste eest võitlejad), mis paremäärmuslike ideedega ei nõustu. Neis nähakse mitmekesisuse jõulisi mahasurujaid ning üheülbalise ja ebaloomuliku tolerantsuse diskursuse propageerijaid.

Samas toimub ka sissepoole suunatud kommunikatsioon, mida on mõttekas käsitleda lähtuvalt Lotmani autokommunikatiivse süsteemi kontseptsioonist. Mina-mina kommunikatsioonis ehk autokommunikatsioonis toimub informatsiooni kvalitatiivne muutus, mis viib lõpuks sellesama mina ümberkujundamiseni: “[...] andes teadet edasi iseendale, kujundab ta oma olemust sisemiselt ümber, kuivõrd isiksuse olemust võib tõlgendada sotsiaalselt tähenduslike koodide individuaalse valikuna, see valik aga siinkohal kommunikatsiooniakti käigus muutub" (Lotman 2010: 130). "Funktsionaalselt kasutatakse teksti mitte teate, vaid koodina siis, kui ta ei lisa juba olemasolevatele uusi teadmisi, vaid transformeerib teksti loonud isiksuse enesemõtestamist ning tõlgib juba olemasoleva teate uude tähenduste süsteemi" (Lotman 2010: 141). Põhimõtteliselt on paremäärmusliku sissepoole suunatud autokommunikatsiooni näol tegemist analoogse situatsiooniga, kus toimub info modelleerimine läbi enesemudeli-filtri. Tähenduslikuna tajutud infokildude erinevad variandid osutavad tegelikult ühele ja samale invariandile: juutide juhitud eliidi vandenõule, mille eesmärk on õõnestada rahvusriike, sealhulgas Eestit. Uus info, mis niisuguse 
autokommunikatsiooni käigus ilmneb, süvendab ja laiendab selle vandenõu tajumise ulatust ja kõikvõimsust. Käesoleval juhul selgub paremäärmuslaste blogipostitustest, et ka kohalikke ACTA ratifitseerimiskõnelusi juhivad samad kuritahtlikud kosmopoliitsed jõud, mis on maailma juba pikemat aega oma dekadentlikul kursil hoidnud. Näiteks nähakse samade jõudude tegevust nii maailmasõdade puhkemise kui ka rahvusriike õõnestavate organisatsioonide, nagu EL ja NATO, loomise taga. Info kvalitatiivne muutus saab võimalikuks, kuna lisandub uus (antud juhul juriidilis-õiguslik) kood ning "lähtesõnum kodeeritakse ümber selle struktuuriühikutesse ning sellele antakse u u e sõnumi jooned" (Lotman 2010: 129). Enesemudelist pärinev seosteraamistik, mis organiseerib paremäärmuslaste kõige erinevamaid tõlgendusi, leiab tänu uue koodi lisandumisele n-ö taas kord tõestust, ning seetõttu on neil juutide juhitud uues maailmakorras järjest vähem põhjust kahelda.

\section{Kokkuvõte}

Analüüsisime käesolevas artiklis eesti paremäärmuslaste paradoksaalset tähendusloomet, mis seob ühes diskursuses kokku pealtnäha vastandlikesse registritesse kuuluvad tähistajad. ACTA-vastaseid postitusi uurides kohtasime samas tähenduslikus tervikus nii sõnavabadust kui ka rassismi ja ksenofoobiat markeerivaid tähistajaid. Selgitasime sellist loogikat lähtuvalt kultuurisemiootika enesemudeli ja Essexi koolkonna tühja tähistaja kontseptsioonist. EI ACTAle funktsioneeris tühja tähistajana, mis koondas vastandlikke tähistajaid ning enesemudeleid ühtsesse diskursusesse, mida identifitseerivaid piire ta seejärel kehastama hakkas. Enesemudel võimaldas selgitada, miks on mõnel tähistajal suurem potentsiaal saada diskursuse dominandiks. Siinkohal on oluline tähele panna, et enesekirjelduste aluseks olev "metakeel pole laenulist päritolu, vaid üks süsteemi enda keeleklassidest” (Lotman 2006: 219). See tähendab, et metakeeles esitatud enesemudel peab olema orgaaniliselt seotud kirjeldatavaga. Meile tundub, et eesti paremäärmuslikus tähendusloomes on teatud diskursust koondavad nimed - tühjad tähistajad - tõenäolisemad kui teised, kusjuures nad funktsioneerivad enesemudeli metatasandil koodina. EI ACTAle ümber koondunud diskursus tugines sõnavabadust rõhutavale enesemudelile, mis kattus paljuski avalikus diskursuses prevaleeriva e-Eesti enesemudeliga. Sõnavabadus lõi ACTA paremäärmuslikus retseptsioonis diskursusesisese hierarhia sinna kuuluvate samaväärsuselementide (sõnavabadus, eraelu puutumatus, kodanike poliitiline aktiivsus jne) vahel ning võimaldas neid siduda rahvusradikaalse enesemudeli ja selle tähistajatega (vaenulikkus seksuaalvähemuste jt vähemusrühmade, iseäranis juutide vastu), kelles nähti maailmapoliitika salajasi niiditõmbajaid ja otseseid sõnavabaduse ohustajaid. 


\section{Kommentaarid}

1 Artikli valmimist toetas Euroopa Liit Euroopa Regionaalarengu Fondi kaudu (Kultuuriteooria Tippkeskus) ja IUT2-44 "Enesekirjeldusmehhanismide semiootiline modelleerimine: teooria ja rakendused".

${ }^{2}$ See blogi pole enam vabalt kättesaadav, aga sama autor on loonud uue blogi aadressil http://toomaskask.blogspot.com/.

${ }^{3}$ Ka see blogi pole enam alates 2013. aasta suvest avalikult kättesaadav, postituste vaatamiseks peab end külastajaks registreerima.

4 Püüame igati vältida oma uurimismaterjali suhtes negatiivsete moraalsete otsuste langetamist ja kasutame terminit paremäärmuslus juhtumitel, kui materjal laseb ennast klassifitseerida eksplitseeritud paremäärmusluse tunnustele tuginedes. Nõustume Cas Mudde'iga (2011a: 79-83), et Teise maailmasõja järgses maailmas on paljude paremäärmuslust käsitlevate uurimuste probleemiks see, et uuritavat ideoloogiat ja selle kandjaid kiputakse nägema kui ühemõtteliselt halba sotsiokultuurilist patoloogiat; mis tõttu jäävad märkamata tänapäevase paremäärmusluse seesmine heterogeensus ja dünaamika.

5 Tõnu Lehtsaar on psühholoog ja Tartu Ülikooli praktilise usuteaduse professor. On esinenud avalikkuses homoseksuaalsust taunivate seisukohtadega. Andres Põder on Eesti Evangeelse Luterliku Kiriku peapiiskop.

6 Ernst Zündel on tuntud saksa päritolu holokausti eitaja, kes deporteeriti selle eest Kanadast Saksamaale, kus talle määrati 2007. aastal 5 aasta pikkune vanglakaristus.

\section{Kirjandus}

Atton, Chris 2006. Far-right media on the internet: culture, discourse and power. New media \& Society 8/4, lk 573-587 (doi: 10.1177/1461444806065653).

Back, Les 2002a. When Hate Speaks the Language of Love. Ettekanne konverentsil Social Movement Studies Conference, London School of Economics. Aprill 2002.

Back, Les 2002b. Aryans reading Adorno: cyber-culture and twenty-firstcentury racism. Ethnic and Racial Studies 25/4, lk 628-651 (doi: 10.1080/01419870220136664).

Ballinger, Dean 2011. Conspiratoria: the Internet and the Logic of Conspiracy Theory. The University of Waikato, the department of Screen and Media Studies. Doctoral thesis.

Barthes, Roland 1977 [1971]. From Work to Text. Image-Music-Text. New York: Hill and Wang, lk 155-164.

Boyer, Dominic 2010. Digital Expertise in Online Journalism (and Anthropology). Anthropological Quarterly 83, lk 73-96 (http://www.anth.rice.edu/uploadedFiles/ People/Faculty_and_Staff_Profiles/Boyer_Documents/Digital\%20Expertise\%281\%29. pdf-17. aprill 2014).

Campbell, Alex 2006. The search for authenticity: An exploration of an online skinhead newsgroup. New media \& Society 8/2, lk 269-294 (doi: 10.1177/1461444806059875).

Cammaerts, Bart 2009. Radical pluralism and free speech in online public spaces. The case of North Belgian extreme right discourses. International Journal of Cultural Studies 12/6, lk 555-575 (doi: 10.1177/1367877909342479). 
Gilroy, Paul 1992. The End of Antiracism. Donald, James \& Rattansi. Ali (toim). Race, Culture and Difference. Thousand Oaks, CA, London \& New Delhi: Sage, lk 49-61.

Griffin, Roger 2002. The incredible shrinking ism: the survival of fascism in the postfascist era. Patterns of Prejudice 36/3, lk 3-8 (doi: 10.1080/003132202128811457).

Griffin, Roger 2008. Fascism's New Faces (And New Facelness) in the 'post-fascist' Epoch. Feldman, Matthew (toim). A fascist century. Essays. New York: Palgrave, lk 181-202.

Griffin, Roger 2011. Limaseenest risoomini: sissejuhatus grupuskulaarsesse parempoolsusse. Vikerkaar 9, lk 53-72 (http://www.vikerkaar.ee/index1.php?page=Arhiiv\&a_act=article\&a_ number $=5328-17$. aprill 2014).

Howard, Robert Glenn 2008. Electronic Hybridity: The Persistent Processes of the Vernacular Web. Journal of American Folklore 121, lk 192-218 (doi: 10.2307/20487596).

KaPo 2012 = Puusepp, Harrys (koost). Kaitsepolitsei aastaraamat. Tallinn: Uniprint.

Laas, Oliver 2011. Protseduurne retoorika ja kinkivad brikolöörid. Vikerkaar 4-5 (http:// www.vikerkaar.ee/?page=Arhiiv\&a_act=article\&a_number $=5260-17$. aprill 2014).

Laclau, Ernesto 1996. Why do empty signifiers matter to politics? Laclau, Ernesto (toim). Emancipation(s). London \& New York: Verso, lk 36-46.

Laclau, Ernesto 2002. Miks on tühjad tähistajad poliitikas olulised. Akadeemia 6, lk 1180-1203.

Laclau, Ernesto 2005. On Populist Reason. London \& New York: Verso (http:// doublesession.net/indexhibitv070e/files/laclau-on-populist-reason.pdf-21. aprill 2014).

Laclau, Ernesto 2006. Ideology and post-Marxism. Journal of Political Ideologies 11(2), lk 103-114 (doi: 10.1080/13569310600687882).

Landow, P. George 2006. Hypertext 3.0: Critical Theory and New Media in an Era of Globalization. Baltimore: The Johns Hopkins University Press.

Lotman, Juri 1999. Semiosfäärist. Tallinn: Vagabund.

Lotman, Juri 2006 [1978]. Semiootilise süsteemi dünaamiline mudel. Kultuurisemiootika. Tallinn: Olion, lk 214-233.

Lotman, Juri 2010 [1970]. ‘Kultuuri õpetamise’ probleem kui tüpoloogiline karakteristik. Salupere, Silvi (toim). Kultuuritüpoloogiast. Tartu: University Press, lk 60-80.

Lotman, Juri \& Uspenski, Boriss 2013a [1971]. Kultuuri semiootilisest mehhanismist. Vene kultuuri jõujooni. Valik artikleid. Tartu: Ilmamaa, lk 207-239.

Lotman, Juri \& Uspenski, Boriss 2013b [1977]. Duaalsete mudelite rollist vene kultuuri dünaamikas XVIII sajandi lõpuni. Vene kultuuri jõujooni. Valik artikleid. Tartu: Ilmamaa, lk 240-294.

Mudde, Cas 1996. The War of Words: Defining The Extreme Right Party. West European Politics 19/2, lk 225-248 (doi: 10.1080/01402389608425132).

Mudde, Cas 2011a. Populistlik paremradikaalsus: patoloogiline normaalsus. Vikerkaar 9, lk 78-88 (http://www.vikerkaar.ee/index1.php?page=Arhiiv\&a_act=article\&a_number=5329 -21. aprill 2014).

Mudde, Cas 2011b. Who's Afraid of the European Radical Right? Dissent 58/4, lk 7-11 (doi: 10.1353/dss.2011.0090). 
Siibak, Andra 2012. Changes in the user practices: the case of extreme nationalist users of SNS Rate. Social Media: Risks and Opportunities in Military Applications. Tallinn: The Research and Technology Organisation of NATO.

Sommer, Bernd 2008. Anti-capitalism in the name of ethno-nationalism: ideological shifts on the German extreme right. Patterns of Prejudice 42/ 3, lk 305-316 (doi: 10.1080/00313220802204046).

Soukup, Charles 2008. 9/11 Conspiracy Theories on the World Wide Web: Digital Rhetoric and Alternative Epistemology. Journal of Literacy and Technology 9/3, lk 2-25 (http:// www.literacyandtechnology.org/volume9_3/jlt_v9_3_soukup.pdf - 21. aprill 2014).

Taguieff, Pierre-André 1999. The New Cultural Racism in France. Bulmer, Martin \& Solomos, John (toim). Racism. Oxford: Oxford University Press, lk 206-213.

\title{
Summary
}

\section{Extreme Right Freedom of Speech in Estonian Radical Nationalists' Online Communication}

\author{
Mari-Liis Madisson, Andreas Ventsel
}

Keywords: cultural semiotics, Essex School of discourse theory, extreme right, identification in hypermedia, ratification of ACTA, self-model

The article focuses on the processes of identification in hypermedia, trying to explicate the strategies of self-description that prevail on the websites of the activists of the Estonian extreme rights. The extreme right movements tend to use generally accepted discourses for the purpose of legitimising their own ethnocentric media practices. Extreme nationalist ideas form equivalences with concepts from the discourse of multiculturalism ('justice', 'freedom', 'democracy', 'freedom of speech'), though at first sight they are incompatible. To explain this paradoxical situation, the authors employ the concepts of the hegemonic logic of signification and the empty signifier, as elaborated by Laclau, as well as the theoretical framework of cultural semiotics. The case-study is based on the extraordinarily forceful public feedback that followed the discussions about ACTA ratification in Estonia. 'Information-freedom' became an ambiguous core signifier: it played an important part in public discussions, but it also had a central role in the self-descriptions of Estonian radical nationalists. NO ACTA functioned in this case as an empty signifier, which united into a discursive whole these contradictory signifiers and self-models. The concept of a self-model is useful for explaining why some signifiers have a greater potential to become discursive dominants. It seems that in Estonian extreme-right meaning creation there are certain relations of equivalence between signifiers that are more likely to aggregate the discourse than the others, and these depend on the abstract level of the self-model. 